 \\ z Filologii Polskiej i Słowiańskiej
}

\author{
Барбара Родзевич \\ (Щецинский университет)
}

\section{Восприятие мира поляками и русскими в свете показаний ядра языкового сознания (на материале ассоциативных словарей)}

Изучение языкового сознания, т.е. своеобразного «внутреннего лексикона человека» (Кубрякова, 1991, с. 91) или «совокупности образов сознания, формируемых и овнешняемых с помощью языковых средств - слов, свободных и устойчивых словосочетаний, предложений, текстов и ассоциативных полей» (Тарасов, 2000, с. 26), содержится в концепции современных исследований языковой картины мира, проводимых в рамках антропологической лингвистики, которая изучает человеческий фактор в языке, рассматривая язык не только и не столько как систему знаков в их взаимоотношениях, но прежде всего как фактор, определяющий человеческое мышление об окружающем мире и способы его восприятия.

В языковом сознании, определяемом иногда также термином этнокультурное сознание, под которым понимается «результат отражения и восприятия образа мира в соответствии с особой сеткой ценностно-смысловых координат, представляющих содержательные контуры той или иной национальной культуры» (Гурочкина, 2001, с. 122-123)

This is an Open Access article distributed under the terms of the Creative Commons Attribution 3.0 PL License (creativecommons.org/licenses/by/3.0/pl/), which permits redistribution, commercial and non-commercial, provided that the article is properly cited. (c) The Author(s) 2018.

Publisher: Institute of Slavic Studies, Polish Academy of Sciences

[Wydawca: Instytut Slawistyki Polskiej Akademii Nauk] 
хранятся все понятия и слова языка, которыми пользуется индивид. Фиксация понятий, их значений и стоящих за ними концептуальных структур в языковом сознании происходит в результате внутренней переработки и упорядочивания передаваемых внешним миром сообщений, которые усваиваются человеком прежде всего в процессе вербальной коммуникации. Психофизиологические исследования уже довольно давно подтвердили, что каждое понятие вплетено в форме логогена (узла в структуре словесной памяти) - физиологического «эквивалента», модели понятия со всеми его внешними характеристиками - акустикой, значением, структурой, взаимоотношениями с другими понятиями, функциями, визуализацией - в сложную, иерархически организованную сеть, обладающую определенной сгущенностью (силой или теснотой связанности слов), сочетающуюся с очередными вербальными сетями, вне которых отдельные понятия не существуют - запрос одного понятия всегда активизирует элементы другой понятийно-вербальной сети (Chlewiński, 1999; Morton, цит. за: Reeves, Hirsh-Pasek, \& Golinkoff, 2005; Ушакова, 1979 et al.). Закрепленные в сознании понятия передают, с одной стороны, личный опыт индивида, приобретенный им в ближайшей среде, с другой стороны, они отражают транслируемые различными способами опыт, умение и знания определенной общественной группы и культуры. В упрощенном смысле языковое сознание - это опосредованный языком образ мира известного культурного (этнического) сообщества.

Одной из стратегий эмпирических исследований языкового сознания с целью выявить межпонятийные (межлогогенные) связи (а также установить семантические профили и коннотации отдельных слов) и, следовательно, получить доступ к языковой картине мира и способам её реконструкции, в том числе и в рамках сравнительных межкультурных исследований, является свободный ассоциативный эксперимент. Тест свободных вербальных ассоциаций основывается, среди прочего, на идее Эдварда Сепира, утверждающего, что внутреннее содержание языков одно и то же - интуитивное знание опыта, и только внешняя форма разнообразна в различных культурах, будучи в то же время довольно стереотипной для каждой конкретной культуры (Сепир, 2001, сс. 223-247). В этом отношении ассоциативный эксперимент - ключ к вскрытию культурного кода, определяемого Войцехом Хлебдой как «исторически сформированная система знаков, воображений и убеждений, организованная элементами родной культуры и взаимодействующих с ней культур, система, которая, 
создавая общность значений и отсылок, обеспечивает ощущение единства данного национального сообщества» (Chlebda, 2000, c. 169).

Разделяя мысль Сепира, в русле исследовательской кросс-культурной программы сектора психолингвистики и теории коммуникации Института языкознания РАН «Сопоставительное исследование национального языкового сознания славян» ${ }^{1}$ автором настоящей статьи и сотрудниками из Щецинского университета был проведен массовый эксперимент с носителями польского языка, студентами в возрасте от 18 до 25 лет, обучающимися в польских университетах различным специальностям (математиками, физиками, биологами, экономистами, филологами, психологами, юристами, журналистами, педагогами). Он заключался в том, что каждый из 500 испытуемых (250 женщин и 250 мужчин) получил анкету со 110 словами-стимулами и должен был реагировать на каждый стимул первым пришедшим в голову словом или словосочетанием. Собранный таким способом материал подвергался обработке и был использован для составления, состоящего из двух частей прямого (SR - от стимула к реакции) и обратного (RS - от реакции к стимулу) польского ассоциативного словаря (Gawarkiewicz, Pietrzyk, \& Rodziewicz, 2008).

В данном исследовании описываются и анализируются особенности языкового сознания носителей польского и русского языков. Обсуждаемый вопрос связан с последним этапом обработки и исследования результатов ассоциативного теста - выявлением ядра языкового сознания поляков на основе данных обратного ассоциативного словаря, т.е. совокупности слов, появившихся в качестве реакций, которые в ассоциативно-вербальных сетях имеют наибольшее число связей со словами, выступившими в качестве стимулов, и сопоставлением его с данными ядра языкового сознания русских. Анализ ядер языкового сознания является наиболее продуктивным не только в области сходств и различий в ментальных отображениях отдельных понятий у представителей двух разных культур, но, прежде всего, относительно системности образа мира как некого этнокультурного целого (вместе с содержащимися в нем стереотипами и стоящими за ними особенностями национального менталитета), закрепленного в эмпирическом лексиконе - ассоциативных тезаурусах обоих языков. Слова, составляющие ядро языкового сознания русских и характеризирующие их количественные данные, приводятся по данным Славянского ассоциативного словаря вслед за Натальей В. Уфимцевой (Уфимцева, 2000, с. 218).

\footnotetext{
1 Подробнее об исследовании: Уфимцева, 2000.
} 
Ядро языкового сознания поляков и русских (первые 30 слов) ${ }^{2}$

\begin{tabular}{|c|c|c|c|c|c|c|}
\hline & \multicolumn{3}{|c|}{ поляки } & \multicolumn{3}{|c|}{ РУССКИЕ } \\
\hline & Ранг & Ассоциат & $\begin{array}{c}\text { Количество реакций } \\
\text { и стимулов }\end{array}$ & Ранг & Ассоциат & $\begin{array}{c}\text { Количество реакций } \\
\text { и стимулов }\end{array}$ \\
\hline 1 & 1 & radość & $\begin{array}{l}\text { (488 реакций) } \\
51 \text { стимул }\end{array}$ & 1 & жизнь & $\begin{array}{c}\text { (363 реакции) } \\
54 \text { стимула }\end{array}$ \\
\hline 2 & 2 & człowiek & (581) 47 & 2 & человек & (1244) 53 \\
\hline 3 & 3 & miłość & (702) 44 & 4 & дом & (514) 48 \\
\hline 4 & 4 & dom & (549) 42 & 4 & любовь & (253) 48 \\
\hline 5 & 5 & życie & (387) 39 & 4 & радость & (248) 48 \\
\hline 6 & 7 & szczęście & (475) 35 & 6 & хорошо & (384) 46 \\
\hline 7 & 7 & spokój & (226) 35 & 7 & друг & (365) 45 \\
\hline 8 & 7 & nadzieja & (165) 5 & 8,5 & счастье & (334) 40 \\
\hline 9 & 9 & przyjemność & (90) 30 & 8,5 & нет & (102) 40 \\
\hline 10 & 10 & dobro & (320) 27 & 10 & есть & (334) 37 \\
\hline 11 & 13,5 & rodzina & (536) 26 & 11,5 & плохо & (329) 35 \\
\hline 12 & 13,5 & ciepło & (288) 26 & 11,5 & свет & (175) 35 \\
\hline 13 & 13,5 & kobieta & (286) 26 & 13,5 & деньги & (341) 34 \\
\hline 14 & 13,5 & seks & (147) 26 & 13,5 & большой & (333) 34 \\
\hline 15 & 13,5 & strach & (140) 26 & 16 & ребёнок & (240) 33 \\
\hline 16 & 13,5 & wolność & (60) 26 & 16 & мир & (151) 33 \\
\hline 17 & 17,5 & śmierć & (316) 25 & 16 & я & 33 \\
\hline 18 & 17,5 & praca & (121) 25 & 19 & добро & 29 \\
\hline 19 & 20,5 & dziecko & (346) 24 & 19 & жить & 29 (184) \\
\hline 20 & 20,5 & przyjaciel & (197) 24 & 19 & красивый & (135) 29 \\
\hline 21 & 20,5 & siła & (106) 24 & 22 & смерть & (365) 27 \\
\hline 22 & 20,5 & ja & (55) 24 & 22 & сила & (99) 27 \\
\hline 23 & 24 & czas & (204) 23 & 22 & всегда & (82) 27 \\
\hline 24 & 24 & złość & (189) 23 & 25 & сильный & 26 (279) \\
\hline 25 & 24 & pomoc & (115) 23 & 25 & много & (186) 26 \\
\hline 26 & 26 & szkoła & (41) 22 & 25 & всё & 26 (120) \\
\hline 27 & 28 & zło & (462) 21 & 28 & зло & (347) 23 \\
\hline 28 & 28 & smutek & (196) 21 & 28 & любить & 23 \\
\hline 29 & 28 & zabawa & (66) 21 & 28 & время & (144) 23 \\
\hline 30 & 30 & uśmiech & (235) 20 & 30 & день & (285) 22 \\
\hline
\end{tabular}

2 В скобках указана абсолютная частота встречаемости данного слова в качестве реакции на все слова-стимулы. Рядом указано количество разных слов-стимулов, реакцией, на которое является данное слово. 
Ассоциаты в языковом ядре поляков и русских распределяются преобладающим образом по нескольким довольно четко выделяющимся следующим зонам: Чувства и эмоции, Качества, Оценочные концепты, Действия, Человек, причём наибольший процент пересечений единиц сознания наблюдается в первом десятке исследуемого фрагмента ядра - 60. Среди первых десяти слов совпадающими являются шесть слов: жизнь/żсіе, человек/człowiek, дом/dom, любовь/miłość, padocmь/radość и счастьe/szczęście. Формально списки первых 30 слов, вошедших в ядро языкового сознания носителей польского и русского языков, совпадают в 46,6\% (из 30 слов совпадают всего лишь 14).

Опираясь на данные, приведенные в таблице, и последовательность выделенных семантических зон, прослежу основные особенности языкового сознания поляков в сопоставлении с русскими. Они находят выражение в следующем:

Сфера Чувств и эмоций устроена различным образом. Базовые эмоции, имеющиеся как в польском, так и в русском менталитете, - эмоции положительной направленности. Ключевые для польского и русского языкового сознания эмоции проявляются в различающихся рангом, но совпадающих в плане выражения ассоциатах: radość/paдость ${ }^{3}$, miłość/любовь, szczęście/cчacmbe, причём эмоциональное понятие radość (радость) ${ }^{4}$ занимает центральное место в языковом сознании поляков и встречается как реакция 488 раз на 51 стимул из 110 стимулов. Продолжая сопоставление ядерных структур, следует отметить, что в польском ядре бо́льший набор эмоций (9 слов) чем в русском (всего 3 слова). Экспрессивно-эмоциональная окрашенность восприятия мира носителями польского языка выражается в использовании в качестве реакции и других лексем, не имеющих кореллятов в русском ядре. Полякам близка целая гамма положительных эмоций и чувств: spokój (спокойствие), nadzieja (надежда), przyjemność (удовольствие). Респонденты больше всего ценят деревенское и домашнее спокойствие семейной жизни - WIEŚ (деревня) (56 реакций - 11,2\%) ${ }^{5}$, DOM (дом) (44 реакции - 8,8\%), RODZINA

3 Строчными буквами записаны ассоциаты, прописным жирным шрифтом стимулы.

${ }^{4}$ Польские слова сопровождаются в скобках соответствующими словами на русском языке.

${ }^{5}$ В скобках указано число реакций, выраженных ассоциатом на приведённый стимул и определение процентной доли ответивших данным словом или выражением. 
(семья) (7 реакций - 1,4\%). Они ощущают спокойствие вечером - WIECZÓR (16 реакций - 3,2\%) и ночью - NOC (14 реакций - 2,8\%). Nadzieja (надежда) в воображении поляков это ŚWIATŁO (свет) (39 реакций - 7,8\%). Её символизирует цвет ZIELONY (зелёный) (36 реакций - 7,2\%). Надежду дают BÓG (Бог) (6 реакций - 1,2\%), новый DZIEŃ (день) (5 реакций - 1\%) и MIŁOŚĆ (любовь) (4 реакции - 0,8\%). Удовольствие - przyjeтпоść неотделимо в сознании поляков от добра (DOBRO - 18 реакций, 3,6\%), оно доставляется разговором ROZMOWA (13 реакций - 2,6\%) и встречей - SPOTKANIE (8 реакций - 1,6\%), в небольшой степени работой - PRACA (3 реакции - 0,6\%). Поляки получают удовольствие прежде всего, когда едят - JEŚĆ (15 реакций - 3\%), но также, когда предаются воспоминаниям - WSPOMINAĆ (4 реакции - 0,8\%) и оказывают помощь - POMAGAĆ (2 реакции - 0,4\%). Нельзя не подчеркнуть в этом контексте актуальность других понятий, отсутствующих в образах языкового сознания русских, которые обнаруживают склонность поляков к оптимизму: это zabawa (развлечение) и uśmiech (улыбка). Слово zabawa (развлечение) укрепилось в сознании польских респондентов в сочетании со стимулами: RADOŚĆ (радость) (11 реакций - 2,2\%), WESOLY (веселый) (11 реакций - 2,2\%), SPOTKANIE (встреча) (5 реакций - 1\%), GOŚĆ (гость) (3 реакции - 0,6\%). Лучшее время для развлечения по мнению польскоязычных участников ассоциативного эксперимента WIECZÓR (вечер) (5 реакций - 1\%) и NOC (ночь) (3 реакции - 0,6\%). Что же вызывает улыбку у поляков, располагая к смеху или удовольствию? Самой частотной является связь ассоциата uśmiech (улыбка) со стимулами RADOŚĆ (радость) (80 реакций - 16\%) и WESOLY (весёлый) (58 реакций - 11,6\%). Uśmiech (улыбка) - атрибут ребёнка - DZIECKO (12 реакций - 2,4\%) и бабушки ВАВСІА (4 реакции - $0,8 \%$ ).

Высоким эмотивным зарядом обладают ассоциаты с отрицательной окраской: strach (страх), złość (злоба), smutek (грусть). У носителя польского сознания чувство страха вызывают ZLO (зло) (14 ассоциатов - 2,8\%), ŚMIERĆ (смерть) (13 ассоциатов - 2,6\%), WRÓG (враг) (11 ассоциатов - 2,2\%) и WOJNA (война) (7 ассоциатов - 1,4\%), KLAMSTWO (ложь) (3 ассоциата - 0,6\%), OGIEŃ (огонь) (3 ассоциата - 0,6\%). От страха (strach) и злобы (złość) полякам хочется KRZYCZEĆ (кричать) (56 ассоциатов - 11,2\% и 37 ассоциатов - 7,4\%). Испытывая злобу, они начинают прежде всего NIENAWIDZIĆ (ненавидеть) (88 ассоциатов - 17,6\%). Это чувство соотносится также со стимулами WRÓG (враг) (34 ассоциата - 6,8\%) и KŁAMSTWO (ложь) (4 ассоциата - 0,8\%). Относительно грусти (smutek) - она ассоциируется скорее всего с противоположными 
чувствами радости ${ }^{6}$ - RADOŚĆ (68 ассоциатов - 13,6\%), счастья - SZCZĘŚCIE (5 ассоциатов - 1\%) и сопутствует таким явлениям и чувствам, как: ŚMIERĆ (смерть) (46 ассоциатов - 9,2\%), WSTYD (стыд) (17 ассоциатов - 3,4\%) и ZłO (зло) (4 ассоциата - 0,8\%). На поляков наводит грусть (smutek) также CZARNY (чёрный) (3 ассоциата - 0,6\%) цвет. Они становятся меланхоличными, когда им ŹLE (плохо) (28 ассоциатов - 5,6\%).

Характерной особенностью ядра языкового сознания русских по сравнению с поляками является тот факт, что в нём находит яркое выражение качественная и количественная характеристика, отмеченное (Стернин, 1996, с. 102; Уфимцева, 2008, с. 29) свойственное русским стремление все оценить, всему приписать определенное качество, оценку окружающего мира. Конечно, оценка является универсальной категорией. Вряд ли существует язык, в котором она отсутствует. Однако в способах, яркости и частотности выражения оценочных значений языки проявляют свою индивидуальность, своеобразность. Это объясняется главным образом тем, что «оценка относится к интенсиональному аспекту языка, где преломление картины мира в сознании говорящего осложняется целым рядом факторов» (Вольф, 2006, с. 9), среди которых стоит назвать различия в семантической сочетаемости слов, денотативную отнесенность частнооценочных слов, характер шкалы оценочных обозначений, оценочные стереотипы (Вольф, 2006, сс. 9-10).

Практически весь мир воспринимается русскими сквозь призму бинарных шкал хорошо/плохо и нет/есть. Самая высокая позиция в рейтинге оценочных признаков принадлежит ассоциату хорошо, который появляется в качестве реакции на 46 слов-стимулов. Хорошо противопоставляется, конечно, ПЛОХО (152 реакции - 30,4\%), которому, в свою очередь, в сравнительной мере противостоит ХОРОШО (182 реакции - 36,4\%). Хорошо русским ЖИТЬ (71 реакция - 14,2\%), ЕСТЬ (12 реакций - 2,4\%), ДУМАТЬ (11 реакций - 2,2\%) и ПОМОГАТЬ (3 реакции - 0,6\%), ГОВОРИТЬ (2 реакции - 0,4\%) и УСПЕТЬ (2 реакции - 0,4\%), причём лучше всего ВМЕСТЕ (13 реакций - 2,6\%). Важнейшей предпосылкой для того, чтобы воспринимать действительность как хорошую, является наличие в ней определенных ценностей, в первую

6 Зеркальные ассоциаты типа грусть/радость могут отражать также определённую лингвистическую реальность - они указывают на частотную характеристику слова (Клименко \& Супрун, 1977, сc. 17-24). 
очередь этических и социальных, а также материального благополучия: ДОБРО (23 реакции - 4,6\%), СПРАВЕДЛИВОСТЬ (10 реакций - 2\%), ДЕНЬГИ (9 реакций - 1,8\%), СЕМЬЯ (5 реакций - 1\%), ЛЮБОВЬ (3 реакции - 0,6\%), РАБОТА (3 реакции - 0,6\%).

По данным обратного словаря лексема плохо воспроизводится русскими испытуемыми главным образом при мысли о ЗЛЕ (40 ответов - 8\%), ОБМАНЕ (18 ответов - 3,6\%), войне (17 ответов - 3,4\%), СМЕРТИ (12 ответов - 2,4\%), СТЫДЕ (9 ответов - $1,8 \%$ ), т.е. в большинстве случаев оцениваются морально-этические вопросы. Но некоторым плохо также в присутствии БОЛЬНОГО (4 ответа $-0,8 \%)$, ЖАДНОГО (3 ответа $-0,6 \%)$, ВРАГА (3 ответа $-0,6 \%$ ), ДУРАКА (4 ответа - $0,8 \%$ ) и ГЛУПОГО (2 ответа - $0,4 \%)$.

В выражении неодобрительной оценки участвует в качестве реакции также отрицательная частица нет. Для рассматриваемого негативного отношения русских анкетируемых к окружающему миру свойствен общий компонент - наличие крайне нежелательных обстоятельств, событий и явлений, неподвластных контролю, а также таких, отсутствие которых препятствует нормальному течению жизни: СПРАВЕДЛИВОСТЬ (14 реакций - 2,8\%), БОГ (8 реакций - 1,6\%), ВРЕМЯ (8 реакций - 1,6\%), ДЕНЬГИ (8 реакций - 1,6\%), СЧАСТЬЕ (8 реакций - 1,6\%), ВРАГ (4 реакции - 0,8\%), СМЕРТЬ (4 реакции - $0,8 \%)$, ВОЙНА (2 реакции $-0,4 \%)$, ОБМАН (2 реакции - $0,2 \%)$. На другом полюсе оценочной шкалы в качестве реакции появляется слово есть. Связывая слово eсmb с определёнными стимулами, русские констатируют наличие в их мире в первую очередь СЧАСТЬЯ (74 реакции - 14,8\%) и БОГА (42 реакции $-8,4 \%$ ), далее 3ЛА (8 реакций - 1,6\%), СПРАВЕДЛИВОСТИ (8 реакций - 1,6\%), ДЕНЕГ (5 реакций - 1\%), ВРЕМЕНИ (3 реакциИ 0,6\%), ДРУГА (3 реакции - 0,6\%), ЛЮБВИ (3 реакции - 0,6\%) и РАБОТЫ (3 реакции - 0,6\%). Антонимическая пара концептов сферы оценки нет/ ecmb, вызываемая сходными стимулами, отражает свойственную русским амбивалентность в восприятии окружающей действительности, хотя в известном смысле такая амбивалентность в большей или меньшей степени свойственна человеку, внутренний мир которого это мир противоречий, поскольку «субъективность мира человека, а также неоформленность многих мыслей, противоречивость чувств и желаний, о которых свидетельствует психология и жизненный опыт людей, свидетельствует о том, что ментальный мир - это сфера действия противоречий» (Ганеев, 2004, с. 67). 
Обращают на себя внимание и очередные, приводимые русскоязычными респондентами, однако внепарные оценочные понятия - концепты, отсутствующие в польском ядре - много, всегда и всё. Анкетируемые предпочитают всегда и всё делать ВМЕСТЕ (соответственно 25 реакций - 5\% и 8 реакций - 1,6\%). Понятие всё олицетворяет БОГА (17 реакций - 3,4\%), ДЕНЬГИ (6 реакциЙ - 1,2\%), ЛЮБОВЬ (2 реакции - 0,4\%) и НАРОД (2 реакции - 0,4\%). Русским свойственно желание всегда ЖИТЬ (3 реакции - 0,6\%), УСПЕТЬ (3 реакции - 0,6\%) и ПОМОГАТЬ (2 реакции - 0,4\%), они всегда НАДЕЮТСЯ (3 реакции - 0,6\%), но, с другой стороны, им всегда ПЛОХО (5 реакций - 1\%). В русском сознании ассоциат всегда заряжен одновременно положительным смыслом и сочетается с понятиями, отождествляющими панкультурные, этические и витальные ценности СПРАВЕДЛИВОСТЬ (6 реакциЙ - 1,2\%), ДОБРО (3 реакции - 0,6\%), ЖИЗНЬ (2 реакции - 0,4\%).

Концепт много характеризует чаще всего действия - русские много ОБЕЩАЮТ (29 реакций - 5,4\%), ДУМАЮТ (26 реакций - 5,2\%), ГОВОРЯТ (20 реакций - 4\%), ЕДЯТ (15 реакций - 3\%) и ПЬЮТ (9 реакций - 1,8\%). Много в представлении русских - это СЧАСТЬЕ (4 реакции - 0,8\%) и ДОБРО (3 реакции - 0,6\%). Постоянным признаком много являются ДЕНЬГИ (45 реакций - 9\%). Вообще деньги представляют собой одно из существенных понятий в ядре языкового сознания русских (оно не попало в список первых 30 слов польского ядра). Ассоциат деньги появляется 341 раз в качестве реакции на 34 стимула. Слово деньги укрепилось в сочетании со словом ВРЕМЯ (126 реакций - 25,2\%). По всей видимости, в сознании русских весьма прочна позиция афористической сентенции, содержащей обобщение жизненного опыта человека. Вместе с тем русские ТЕРЯЮТ (47 реакций - 9,4\%), ИЩУТ (9 реакций - 1,8\%) и ОБЕЩАЮТ (8 реакций - 1,6\%) деньги. Деньги дают им СИЛУ (7 реакций - 1,4\%) и СЧАСТЬЕ (7 реакций), но ими обладают, как правило, только БОГАТЫЙ (37 реакций - 7,4\%) и ЖАДНЫЙ (16 реакций - 3,2\%).

Важнейшей характеристикой в менталитете представителей русской нации является большой. Самым частотным по отношению к этой реакции оказывается стимул МАЛЕНЬКИЙ (82 реакции - 16,4\%). Большой постоянный эпитет для характеристики ПАЛЬЦА (54 реакции - 10,8\%), PТА (45 реакций - 9\%), ГОРОДА (44 реакции - 8,8\%) и ДОМА (38 реакций $-7,6 \%)$. Не менее важным считается признак сильный, который соотносится со СЛАБЫМ (117 реакций - 23,4\%). Проявление этого 
качества русские видят прежде всего в ВETPE (68 реакций - 13,6\%), МУЖЧИНЕ (37 реакциЙ - 7,4\%), ГОЛОСЕ (12 реакций - 2,4\%), НАРОДЕ (5 реакций - 1\%) и ОГНЕ (5 реакций - 1\%).

Носителями эстетического признака красивый являются в первую очередь МОЛОДОЙ (26 реакций - 5,2\%) и, что интересно, МУЖЧИНА (16 реакций - 3,2\%). Этим признаком русские наделяют также ГОЛОС (10 реакций - 2\%), ДОМ (10 реакций - 2\%), МАЛЬЧИКА (6 реакций - $1,2 \%)$, ГОРОД (4 реакции - 0,8\%) и РЕБЁНКА (4 реакции - 0,8\%).

В сфере Действий тоже обнаруживаются расхождения в двух исследуемых менталитетах. В русском ядре базовыми выступают функциональные концепты есть и жить, менее актуально действие любить (ранг 28). Наиболее частотными по отношению к есть оказываются ПИТЬ (54 реакции - 10,8\%) и ХОТЕТЬ (51 реакция - 10,2\%). Русские предпочитают есть ХЛЕБ (14 реакций - 2,8\%), едят, чтобы приобрести СИЛУ (12 реакций $-2,4 \%)$ и делают это БЫСТРО (8 реакций - 1,6\%). В свою очередь для концепта жить самыми устойчивыми являются связи: жить - ХОРОШО (64 реакции - 12,8\%) и жить - ХОТЕТЬ (29 реакций - 5,8\%). Для русских жить - это НАДЕЯТЬСЯ (8 реакций - 1,6\%), ДУМАТЬ (7 реакций - 1,4\%), ПОМОГАТЬ (5 реакций - 1,2\%), а также ЕСТЬ (2 реакции - 0,4\%) и ПИТЬ (2 реакции - 0,4\%), причём они привыкли жить ВМЕСТЕ (22 реакции - 4,4\%). Поляки же отдают предпочтение активным концептам - seks (секс) и praca (работа). Секс связан с любовью (MILOŚ́ - 31 реакция, 6,2\%). Поляки думают о нём при мысли о женщине - KOBIETA (33 реакции - 6,6\%), реже о мужчине - MĘŻCZYZNA (13 реакций - 2,6\%), ассоциируют его с красным цветом - CZERWONY (10 реакций - 2\%), занимаются им ночью - NOC (10 реакций - 2\%) или вечером - WIECZÓR (5 реакций - 1\%). Днём - DZIEŃ (16 реакций - 3,2\%) - поляки заняты работой. Идея praca (работа) достаточно сильна в менталитете поляков (ранг 17,5). Работой ради денег - PIENIĄDZE (12 реакций - 2,4\%) занимается в основном MĘŻCZYZNA (мужчина) (11 реакций - 2,2\%), в частности, MĄŻ (муж) (4 реакции - 0,8\%). Это показывает, что в сознании поляков фиксируются гендерные стереотипы, представляющие собой культурно и социально обусловленные мнения о нормах поведения представителей полов. Вербализованное в языковом сознании представление о работающем мужчине и муже содержит, по-видимому, традиционную парадигму маскулинности. В данной парадигме отражается одновременно все еще присутствующая в ментальных структурах опрошенных патриархальная модель семейных 
отношений с мужчиной - главой и кормильцем семьи. Для работы поляки используют собственные RĘCE (руки) (62 реакции - 12,4\%).

Нельзя обойти вниманием важность в польском сознании понятия ciepło (тепло), появившегося 288 раз как реакция на 26 слов-стимулов (ранг 13,5). Ciepło (тепло) соотносится конвенциональным образом со стимулами OGIEŃ (огонь) (91 реакция - 18,2\%) и ŚWIATŁO (свет) (12 реакций $-2,4 \%)$. С другой стороны, с теплом ассоциируются DOM (дом) (82 реакции - 16,4\%), RODZINA (семья) (32 реакции - 6,4\%) и члены семьи - МАТКА (мать) (22 реакции - 4,4\%) и ВАВСІА (бабушка) (17 реакций $-3,4 \%)$. Как видно, для традиционного мировоззрения поляков одной из важнейших ценностей, обеспечивающих ощущение безопасности и благосостояния является семья и её женское начало. Такой вывод находит подтверждение также в устройстве семантического гештальта очередной зоны - Человек. Как польскую, так и русскую зону возглавляет człowiek/человек. Сюда входят, различающиеся рангом, но сходные в плане содержания, ассоциаты przyjaciel (ранг 20,5)/ друг (ранг 7), dziecko (ранг 20,5)/ ребёнок (ранг 16) и ја (ранг 20,5)/ я (ранг 16). Однако польский семантический гештальт не исчерпывается указанными выше словами. Ключевое место в нём находят RODZINA (семья) (ранг 13,5) і KOBIETA (женщина) (ранг 13,5) - необходимая спутница мужчины - MĘŻCZYZNA (132 реакции - 26,4\%), жена - ŻONA (58 реакций - 11,6\%), мать - MATKA (29 реакций - 5,8\%), дочь - CÓRKA (9 реакций - 1,8\%) и бабушка - BABCIA (6 реакций - 1,2\%), в то время как для русских человек - это прежде всего ДРУГ.

Резюмируя сказанное, можно сделать вывод, что хотя бы предварительное исследование фрагментов ментального мира поляков и русских через призму ядра языкового сознания позволяет выявить довольно существенные несоразмерные различия в восприятии мира представителями обеих наций. Это одно из веских доказательств правильности утверждений многих исследователей о влиянии языка на мышление и восприятие мира, в том числе вышеприведенных. Даже родственная связь языков не предполагает совпадения языкового образа окружающей действительности их носителей, которые, помимо сходного во многом жизненного опыта, создают собственный особый мир, объективизирующийся через их язык и в их языке.

В заключение следует еще подчеркнуть, что этот беглый анализ не исчерпывает всех аспектов сопоставительных исследований ассоциа- 
тивно-вербальных сетей, присутствующих в ментальных структурах разноязычных участников ассоциативного эксперимента. Его продолжение могут составить и другие, сугубо лингвистические, проблемы, например, подробное исследование семантики ассоциатов, видов их взаимообусловленности и связи, частотности слов, их текстообразующей способности.

\section{Литература}

Chlebda, W. (2000). Płaszczyzny oglądu językowego obrazu świata. In S. Gajda (Ed.), Komparacja systemów i funkcjonowania współczesnych języków słowiańskich (Vol. 1, pp. 163-178). Opole: Wydawnictwo Uniwersytetu Opolskiego.

Chlewiński, Z. (1999). Umyst: Dynamiczna organizacja pojęć. Warszawa: Wydawnictwo Naukowe PWN.

Gawarkiewicz, R., Pietrzyk, I., \& Rodziewicz, B. (2008). Polski słownik asocjacyjny z suplementem. Szczecin: PRINT GROUP.

Reeves, L., Hirsh-Pasek, K., \& Golinkoff, R. (2005). Słowa i znaczenia - od pojęć pierwotnych do złożonych struktur. In J. Berko-Gleason \& N. Bernstein Ratner (Eds.), Psycholingwistyka (pp. 173-247). Gdańsk: Gdańskie Wydawnictwo Psychologiczne.

Вольф, Е. М. (2006). Функциональная семантика оценки. Москва: КомКнига.

Ганеев, Б. (2004). Противоречия в языке и речи. Уфа: Издательство БГПУ.

Гурочкина, А. Г. (2001). Этнокультура и языковое сознание. In Филология и культура: Материалы ІІІ Международной научной конферениии 16-18 мая, 2001 (Pt. 3, pp. 122123). Тамбов: Издательство ТГУ им. Г. Р. Державина.

Клименко, А. П., \& Супрун, А. Е. (1977). Ассоциативный эксперимент в ряду других методов семантических исследований. In A. А. Леонтьев (Ed.), Словарь ассоииативных норм русского языка (рр. 17-24). Москва: Издательство Московского университета.

Кубрякова, Е. С. (1991). Обеспечение речевой деятельности и проблема внутреннего лексикона. In Е. С. Кубрякова, А. М. Шахнарович, \& Л. В. Сахарный (Eds.), Человеческий бактор в языке: Язык и порождение речи (pp. 82-140). Москва: Наука.

Сепир, Э. (2001). Язык. In Э. Сепир, Избранные труды по языкознанию и культурологии (рp. 223-247). Москва: Прогресс.

Стернин, И. А. (1996). Коммуникативное поведение в структуре национальной культуры. In Н. В. Уфимцева (Ed.), Этнокультурная специфика языкового сознания (рp. 97-112). Москва: Эйдос. 
Тарасов, Е. Ф. (2000). Актуальные проблемы анализа языкового сознания. In Н. В. Уфимцева (Ed.), Языковое сознание и образ мира (рр. 24-32). Москва: Институт языкознания РАН.

Уфимцева, Н. В. (2000). Языковое сознание и образ мира славян. In Н. В. Уфимцева (Ed.), Языковое сознание и образ мира (рp. 207-219). Москва: Институт языкознания РАН.

Уфимцева, Н. В. (2008). Ассоциативные словари славянских языков. In R. Gawarkiewicz, I. Pietrzyk, \& B. Rodziewicz, Polski słownik asocjacyjny z suplementem (pp. 15-31). Szczecin: PRINT GROUP.

Уфимцева, Н. В., Черкасова, Г. А., Караулов, Ю. Н., \& Тарасов, Е. Ф. (2004). Славянский ассоииативный словарь: Русский, белорусский, болгарский, украинский. Москва: Институт языкознания РАН.

Ушакова, Т. Н. (1979). Функциональные структуры второй сигнальной системы: Психолингвистические механизмы внутренней речи. Москва: Наука.

\section{Bibliography (Transliteration)}

Chlebda, W. (2000). Płaszczyzny oglądu językowego obrazu świata. In S. Gajda (Ed.), Komparacja systemów i funkcjonowania współczesnych języków słowiańskich (Vol. 1, pp. 163-178). Opole: Wydawnictwo Uniwersytetu Opolskiego.

Chlewiński, Z. (1999). Umysł: Dynamiczna organizacja pojęć. Warszawa: Wydawnictwo Naukowe PWN.

Ganeev, B. (2004). Protivorechiia v iazyke i rechi. Ufa: Izdatel'stvo BGPU.

Gawarkiewicz, R., Pietrzyk, I., \& Rodziewicz, B. (2008). Polski słownik asocjacyjny z suplementem. Szczecin: PRINT GROUP.

Gurochkina, A. G. (2001). Ėtnokul'tura i iazykovoe soznanie. In Filologiia i kul'tura: Materialy III Mezhdunarodnoĭ nauchnoı̆ konferentsii 16-18 maia, 2001 (Pt. 3, pp. 122-123). Tambov: Izdatel'stvo TGU im. G. R. Derzhavina.

Klimenko, A. P., \& Suprun, A. E. (1977). Assotsiativnyı̌ èksperiment v riadu drugikh metodov semanticheskikh issledovaniǔ. In A. A. Leont'ev (Ed.), Slovar' assotsiativnykh norm russkogo iazyka (pp. 17-24). Moskva: Izdatel'stvo Moskovskogo universiteta.

Kubriakova, E. S. (1991). Obespechenie rechevoĭ deiatel'nosti i problema vnutrennego leksikona. In E. S. Kubriakova, A. M. Shakhnarovich, \& L. V. Sakharnyı̌ (Eds.), Chelovecheskiu faktor v iazyke: IAzyk i porozhdenie rechi (pp. 82-140). Moskva: Nauka.

Reeves, L., Hirsh-Pasek, K., \& Golinkoff, R. (2005). Słowa i znaczenia - od pojęć pierwotnych do złożonych struktur. In J. Berko-Gleason \& N. Bernstein Ratner (Eds.), Psycholingwistyka (pp. 173-247). Gdańsk: Gdańskie Wydawnictwo Psychologiczne.

Sepir, Ė. (2001). IAzyk. In Ė. Sepir, Izbrannye trudy po iazykoznaniiu i kul'turologii (pp. 223-247). Moskva: Progress. 
Sternin, I. A. (1996). Kommunikativnoe povedenie v strukture natsional'noŭ kul'tury. In N. V. Ufimtseva (Ed.), Etnokul'turnaia spetsifika iazykovogo soznaniia (pp. 97-112). Moskva: Éĭdos.

Tarasov, E. F. (2000). Aktual'nye problemy analiza iazykovogo soznaniia. In N. V. Ufimtseva (Ed.), IAzykovoe soznanie i obraz mira (pp. 24-32). Moskva: Institut iazykoznaniia RAN.

Ufimtseva, N. V. (2000). IAzykovoe soznanie i obraz mira slavian. In N. V. Ufimtseva (Ed.), IAzykovoe soznanie i obraz mira (pp. 207-219). Moskva: Institut iazykoznaniia RAN.

Ufimtseva, N. V. (2008). Assotsiativnye slovari slavianskikh iazykov. In R. Gawarkiewicz, I. Pietrzyk, \& B. Rodziewicz, Polski słownik asocjacyjny z suplementem (pp. 15-31). Szczecin: PRINT GROUP.

Ufimtseva, N. V., Cherkasova, G. A., Karaulov, I. N., \& Tarasov, E. F. (2004). Slavianskiu

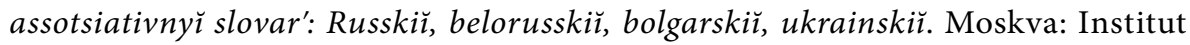
iazykoznaniia RAN.

Ushakova, T. N. (1979). Funktsional'nye struktury vtoroŭ signal'noı̆ sistemy: Psikholingvisticheskie mekhanizmy vnutrenne ̌ rechi. Moskva: Nauka.

Vol'f, E. M. (2006). Funktsional'naia semantika otsenki. Moskva: KomKniga.

\section{Perception of the world by Poles and Russians as demonstrated by indications of the core of language consciousness (on the material of associative dictionaries)}

\section{Summary}

The paper addresses from a psycholinguistic perspective the issue of the linguistic picture of the world of Poles and Russians. The author performs an analysis of the reversed Polish and Russian associative dictionaries that form the so-called cores of language consciousness. 


\section{Postrzeganie świata wśród Polaków i Rosjan w świetle wskazań jądra świadomości językowej (na materiale słowników asocjacyjnych)}

\section{Streszczenie}

W artykule badana jest z perspektywy psycholingwistycznej kwestia językowego obrazu świata Polaków i Rosjan. Autorka dokonuje analizy odwróconych słowników asocjacyjnych języków polskiego i rosyjskiego, stanowiących tak zwane jądra świadomości językowej.

Keywords: linguistic picture of the world; free word association test; verbal associative network; Polish associative dictionary; Russian associative dictionary

Słowa kluczowe: językowy obraz świata; test swobodnych skojarzeń słownych; sieć skojarzeń słownych; polski słownik asocjacyjny; rosyjski słownik asocjacyjny

Barbara Rodziewicz, Institute of Slavic Philology, Faculty of Philology, University of Szczecin Correspondence: barbara.rodziewicz@usz.edu.pl

This article was self-financed by the author.

Competing interest: The author has declared that she has no competing interests. 